\title{
Factors Affecting Farmer's Decision to Use Loan at Rice-Fish Farming in Seyegan District, Sleman Regency, Yogyakarta
}

\author{
Herdi Appas $^{1^{*}}$, Masyhuri² Jamhari $^{3}$ \\ ${ }^{1}$ Postgraduate Agribusiness Management, Faculty of Agriculture, Universitas Gadjah Mada, Jl. Flora \\ No. 1 Bulaksumur, Yogyakarta \\ ${ }^{2,3}$ Faculty of Agriculture, Universitas Gadjah Mada, Jl. Flora No. 1 Bulaksumur, Yogyakarta
}

Received: 25 September 2018; Revised: 28 September 2018; Accepted: 2 October 2018

\begin{abstract}
Capital is one of the important aspects in the development of farming system because with large capital, it is expected that the farming will run more and provide welfare for farmers who do the farming. Capital can be obtained from external sources by using loan. This research aims to determine the factors that influence the decision of farmers to use loan at Rice-Fish farming in Seyegan District, Sleman Regency, Yogyakarta. In this research, data were collected from 50 respondents by questionnaires and interviews with proportional sampling method where 25 respondents were taken from Margodadi Village, Seyegan District and adjusted to take 25 respondents from Margoluwih Village, Seyegan District. To analyze the factors that influence the decision of farmers using loan used Binary Logistic Regression Model. Partial test result shows that variables influence farmer's decision to borrow money are farmer's education level, land area, the use of fish seeds, and loan procedures.
\end{abstract}

Keywords: binary logistic regression; loan; rice-fish farming

\section{How to cite:}

Appas, H., Masyhuri, \& Jamhari. (2018). Factors Affecting Farmer's Decision to Use Loan at Rice-Fish Farming in Seyegan District, Sleman Regency, Yogyakarta. Habitat, 29(2), 76-83. https://doi.org/10.21776/ub.habitat.2018.029.2.9

\section{Introduction}

The main and most often encountered problem in any field of business is always inseparable from the need for funds (capital). The need for these funds is required either for investment capital or working capital. Funds are needed both for new businesses and those that have been running for years. Alternative financing can be done through financial institutions or often called financing institutions. Currently there are various types of financing institutions in Indonesia, ranging from traditional class to modern class are available. The main activity of financial institutions is to finance the capital of a business field in addition to other businesses such as to accommodate money that has not been used by the owner for a while. In addition, other activities of financial institutions can-not be separated from financial services (Susetyo, 2011).

*Penulis Korespondensi

E-mail: herdi.appas.01080@gmail.com
Capital is an indispensable thing in establishing a business, whether it is small, medium or big scale. Sources of capital can come from formal financial institution credits consisting of conventional banks, syariah banks, and non-formal financial institutions such as middlemen or own capital. The main problem that often faced in developing agribusiness is capital. It becomes a challenge faced by the agribusiness actors in developing their business (Sholihah et al., 2014).

The need for capital in the development of Indonesia's agricultural sector is urgent. This is supported by the fact that most Indonesian farmers are small farmers and the characteristic of the agricultural activities in developing countries is labor intensive due to the limited capital. On the other hand, banks tend to be cautious in providing credit to the agricultural sector due to relatively high business risks and low profit rates. This causes the slow process of capital formation in the agricultural sector which further slows the increase in productivity. Perwitasari et al. (2011) mentioned that capital loans are very beneficial for the farmers because 
it can increase income, business volume, and employment.

Burhansyah (2014) mentioned that one of the problems of agricultural development is the low level of innovation adoption from the farmers and capital level, therefore a research related to the problem was conducted. Wati (2015) in her research on access of micro credit to organic rice farmers in Bogor district concluded that farmers have access to micro credit is only limited to semiformal institutions such as cooperatives and farmers group.

The influence of demand for loan is not only focused on the banking sector alone as a creditor, but needs to be viewed from the perspective of society as a debtor such research conducted by Aisyah (2013). Research on perception and attitude analysis as well as factors influencing the farmer's interest to use loan for farming in Asahan District views internal and external factors from the farmers that influence their interest to borrow the money.

Each region has behavioral characteristics and perceptions of each farmer in using the loan on their farm. This has an impact on the interest of farmers in using both formal and informal sources of financing on the farms that are being run. Therefore, information about behavioral characteristics, perceptions, and factors that affect farmers in using the financing for farming in an area.

One of the farms applied in Sleman Regency noticed is the Rice-Fish culture systems. Rice-Fish culture is a new breakthrough in rice farming that is integrated with fish farming. The system which was introduced by Sleman Regency Agricultural Office in 2011 is expected to increase farmer's income (Lantarsih, 2016). The success of the freshwater fish cultivation program in paddy fields of rice farming developed in Sleman Regency received appreciation from the Food and Agriculture Organization (FAO) so that the region became a world model in 2015. The Food and Agriculture Organization of the World or FAO has recognized the method of freshwater fish cultivation in the fields rice farming as a part of the global leading agricultural programs. Because the Rice-Fish culture is a joint effort between the cultivation of fish and rice, it certainly requires more capital in its management. Capital can be obtained by borrowing money in formal and non-formal financial institutions. But here it is necessary to see the interest of farmers in obtaining capital especially from loans.

The sustainability of Rice-Fish farming is strongly influenced by the availability of capital. At present many farmers have stopped Rice-Fish farming because of lack of capital. Indeed, farmers initially received capital assistance from FAO to run their farms. But this capital is a revolving loan which means farmers must return the capital borrowed by them. Whereas this Rice-Fish farming is very beneficial for the community. The benefits gained by the presence of Rice-Fish farming are the creation of community empowerment (Lestari \& Bambang, 2017). So it's a pity if a lot of Rice-Fish farming stopped because of lack of capital in its management. So this is the background of the author to conduct research on Rice-Fish farming capital in Seyegan District, Sleman Regency, Yogyakarta.

Problem in this journal research related to capital and loan in Rice-Fish farming system are what factors influence the farmer decision in using loan at Rice-Fish farming in Seyegan District, Sleman Regency, Yogyakarta. After the problem is found, it can be seen that the purpose of writing this article is to know the factors that influence the farmer's decision in using the loan at Rice-Fish culture system farm in Seyegan District, Sleman Regency, Yogyakarta.

\section{Methods}

\subsection{Location and Data}

The selection of the research location was purposive with the consideration that Seyegan District, Sleman Regency is a Rice-Fish farming demonstration place by FAO. Samples were taken from two villages in Seyegan District, which are Margoluwih Village and Margodadi Village. The data collected consist of primary data and secondary data. Primary data were obtained from interviews with Rice-Fish farmers in Seyegan District. The number of respondents taken from each village is 25 people by using proportional sampling method. According to Chao (2010), proportional sampling is a sampling method where researchers divide the limited population into subpopulations and then apply sampling techniques to each subpopulation.

\subsection{Analysis Method}

The analysis of factors affecting the farmer's decision in using loan at Rice-Fish 
farming in this research used Binary Logistic Regression Model. Binary Logistic Regression Model can obtain the correlation of factors affecting the farmer's decision to use loan through internal and external factors that exist in respondent which become the object of this research.

This research is different from other research that usually discuss analysis of factors. The difference can be seen in the analysis model used. Other research usually used Multiple Regression Model. But in this research, the analysis model used was Binary Logistic Regression Model.

This research used Binary Logistic Regression Model. This analysis is used to analyze qualitative data reflecting the choice between the two alternatives like yes or no. This model is a way to quantitize the relationship between the probability of two choices with some of the selected characteristics. Dependent variable in this research is $0=$ not borrowing and $1=$ borrow. Equation formulas for this model are:

$$
L_{i}=\operatorname{Ln}\left(\frac{P}{1-P i}\right)=\beta_{0}+\beta_{1} X_{1}+\beta_{2} X_{2}+\ldots+\beta_{m} X_{m}
$$

Where:

$\beta_{0}=$ Constants

$\mathrm{Y}=$ The decision to use the loan $(0=$ not borrowing; 1 = borrow)

$\mathrm{X}_{1}=$ Farmer's age (year)

$\mathrm{X}_{2}=$ Farmer's education level (score)

$\mathrm{X}_{3}=$ Area of land $\left(\mathrm{m}^{2}\right)$

$\mathrm{X}_{4}=$ The use of rice seed $(\mathrm{kg})$

$\mathrm{X}_{5}=$ The use of fish seed $(\mathrm{kg})$

$\mathrm{X}_{6}=$ Farming experience (year)

$\mathrm{X}_{7}=$ Perception about interest rate (score)

$\mathrm{X}_{8}=$ Perception about loan procedure (score)

$\mathrm{X}_{9}=$ Perception about collateral (score)

\subsection{Model Test}

The model used should be feasible or meet the Goodness of Fit (GoF). A model is categorized as fulfilling GoF if there is a match between the data entered in the model and the observed data. In Binary Logistic Regression Model, methods to test model feasibility typically are Pearson Method, Deviance, and Hosmer-Lemeshow.

In practice, the use of the Pearson method is based on Pearson test statistics formulated as follows:

$$
X^{2}=\sum_{i=1}^{n} \frac{\left(O_{i}-e_{i}\right)^{2}}{e_{i}}
$$

In this case $\mathrm{O}_{\mathrm{i}}$ denotes the frequency of the $\mathrm{i}$-th observations and $e_{i}$ denotes the expected frequency of $i$, where $i=1,2,3, \ldots n$. The rule of the decision is $\mathrm{H}_{0}$ is rejected if $\mathrm{X}^{2}{ }_{\text {score }}>\mathrm{X}_{\alpha(\mathrm{n} \mathrm{p})}$. In this case (n-p) is the degrees of freedom, $n$ denotes the number of groups and $\mathrm{p}$ represents the number of parameters in explanatory variables.

The Deviance method test is based on the likelihood ratio criterion by comparing the model without explanation to the model with the explanation (full model). Deviance test statistics is formulated as follows:

$$
D=-2 \sum_{i=1}^{n}\left[y i \operatorname{Ln}\left(\frac{\hat{A} i}{y i}\right)+(1-y i) \operatorname{Ln}\left(\frac{1-\hat{\pi} \hat{i} i}{1-y i}\right)\right]
$$

Statistic D follows the distribution of $\mathrm{X}^{2}$ with the degrees of free $n-p$. The rule of decision is to reject $\mathrm{H}_{0}$ if $\mathrm{D}_{\text {score }}>\mathrm{X}_{\alpha(\mathrm{n}-\mathrm{p}) \text {. }}^{2}$

The Hosmer-Lemeshow test is conducted on the basis of grouping on the expected value of $X^{2}$ spread probability. Hosmer-Lemeshow test statistics is formulated as follows:

$$
\hat{C}=\sum_{k=1}^{g} \frac{\left(O_{k}-n_{k}^{g} \bar{\pi}_{k}\right)^{2}}{n_{k}^{g} \bar{\pi}_{k}\left(1-\bar{\pi}_{k}\right)}
$$

In this case, "g" denotes the number of groups; $n_{k}^{z}=$ number of observations in the k-th group; $O_{k}=$ total value of $\mathrm{Y}$ in group to $\mathrm{k}$; and $\bar{\pi}_{k}$ is the average of $\bar{\pi}$ for the k-th group. Statistic C follows the distribution of $\mathrm{X}^{2}$ with degrees of freedom $\mathrm{g}-2$. The decision rule rejects $\mathrm{H}_{0}$ if $\tilde{C}_{\text {count }}>\mathrm{X}_{\alpha(\mathrm{g}-2)}$. The Model is categorized as eligible for GoF if the Hosmer-Lemeshow test result is $<0.05$ (Hendayana, 2013).

In Binary Logistic Regression Model, in order to know the factors that influence the farmer's decision in using the loan at Rice-Fish farming, several tests can be done, among others are:

a. Simultaneously Test

This test is performed to examine the significance of the $\beta$ coefficients to the dependent variable simultaneously.

Hypothesis:

$\mathrm{H}_{0}: \beta 1=\beta 2=\cdots=\beta k=0$ (no independent variables affect the dependent variable) 
$\mathrm{H}_{1}$ : at least one $\beta j \neq 0 ; \mathrm{j}=1,2, \ldots, \mathrm{k}$ (there is influence of at least one independent variable to the dependent variable)

The test statistic used is G test statistic or Likelihood Ratio Test as stated by Hosmer \& Lemeshow (2013):

$$
G=-2 \operatorname{Ln}\left[\frac{\text { reduced model }}{\text { full model }}\right]
$$

The rejection zone $\mathrm{H}_{0}$ is if $\mathrm{G}^{2}>\mathrm{X}_{(\alpha, d f)}$ with $\mathrm{df}$ is the number of parameters in the model or $\mathrm{p}$ value $<\alpha$. The test statistic G follows the ChiSquare distribution with $\mathrm{df}$ or $\mathrm{p}$-value $<\alpha=$ 0.05 .

Simultaneous test results can be seen through the level of significance of regression output in the omnibus table test of model coefficient indicating that the significance number $\alpha<0.05$ indicates that the independent variables simultaneously affect the dependent variable.

b. Partially Test

This test is performed to examine the meaning of the coefficient $\beta$ partially.

Hypothesis:

$\mathrm{H}_{0}: \beta j=0$ (no independent variable influence is tested against the dependent variable)

$\mathrm{H}_{1}: \beta j \neq 0 ; \mathrm{j}=1,2, \ldots, \mathrm{k}$ (there is influence of independent variables tested against the dependent variable)

The test statistic used is Wald's test statistic as stated by Hosmer \& Lemeshow (2013):

$$
W=\left[\frac{\beta \mathrm{j}}{S E(\beta \mathrm{j})}\right]
$$

The rejection region $\mathrm{H}_{0}$ is $\mathrm{W}^{2}>\mathrm{X}_{(\alpha, d f)}$ with $\mathrm{df}=$ 1 or $\mathrm{p}$-value $<\alpha=0.05$.

The model used should be feasible or meet the Goodness of Fit (GoF). A model is categorized as fulfilling GoF if there is a match between the data entered in the model and the observed data. The method used to test the model feasibility typically is the HosmerLemeshow Test.

Binary Logistic Regression Model can see whether the independent variables significantly affect the farmer's decision to use the loan. The overall result of logistic regression analysis is processed through SPSS. With logistic regression can be seen the significance of both simultaneously and partially, then can be seen the value of B (Slope) in forming regression equation and odd ratio that happened which will explain the decision of farmer using loan at Rice-Fish farming in Seyegan District.

\section{Results and Discussion}

Seyegan District is one of the districts in Sleman Regency, Yogyakarta. Seyegan District is in the Southwest of the Capital of Sleman Regency. Seyegan District was used as a RiceFish farming center because the Rice-Fish farming system conducted there was considered successful. So that FAO appreciates and makes Seyegan District as a world model for the RiceFish farming system. FAO recognizes Rice-Fish farming as part of one of the leading global agricultural. Rice-Fish farming is a type of business that requires more capital than the rice farming alone because in Rice-Fish farming there are some additional costs incurred that include the cost of fish seed and fish feed plus other equipments which are not found in rice farming.

First step in Binary Logistic Regression Model can be seen in Table 1. The table shows that the number of samples used in this research was 50 respondents. No missing cases, so the percentage shown was 100 percent.

Table 1. Case processing summary

\begin{tabular}{llrr}
\hline Unweighted Cases & $\mathrm{N}$ & Percent \\
\hline $\begin{array}{l}\text { Selected } \\
\text { Cases }\end{array}$ & $\begin{array}{l}\text { Included in } \\
\text { Analysis }\end{array}$ & 50 & 100.0 \\
\cline { 2 - 4 } & Missing Cases & 0 & 0.0 \\
\cline { 2 - 4 } & Total & 50 & 100.0 \\
\hline \multicolumn{2}{l}{ Unselected Cases } & 0 & 0.0 \\
\hline \multicolumn{2}{l}{ Total } & 50 & 100.0 \\
\hline
\end{tabular}

In Table 2 shows the dependent variable used in this research. Table 2 called table of dependent variable encoding. There are two types of variables, which are $0=$ not borrowing and $1=$ borrow.

Table 2. Dependent variable encoding

\begin{tabular}{lr}
\hline \multicolumn{1}{c}{ Original Value } & Internal Value \\
\hline Not borrowing & 0 \\
Borrow & 1 \\
\hline
\end{tabular}

From the Table 3, can be seen the model summary table. To find out the variables that function in explaining variables, namely Cox \& Snell R Square and Nagelkerke R Square. These values are also called Pseudo R-Square or if in linear regression better known as R-Square. Nagelkerke R Square value is 0.627 and Cox \& Snell R Square 0.468, which indicates that the 
ability variable in explaining dependent variables is 0.627 or $62.7 \%$ and there are $100 \%$ $62.7 \%=37.3 \%$ other factors outside the model explain the dependent variable.

Table 3. Model summary

\begin{tabular}{rrr}
\hline $\begin{array}{c}-2 \text { Log } \\
\text { likelihood }\end{array}$ & $\begin{array}{c}\text { Cox \& Snell } \\
\text { R Square }\end{array}$ & $\begin{array}{c}\text { Nagelkerke } \\
\text { R Square }\end{array}$ \\
\hline 37.065 & 0.468 & 0.627 \\
\hline
\end{tabular}

The Table 4 shows the results of Hosmer and Lemeshow Test. The value of Chi Square table for df 8 (number of independent variables 1) at the 0.05 significance level is 15.507 . Because the value of Chi Square Hosmer and Lemeshow is 11.017 < Chi Square table 15.507 or the significance value equals to $0.201(>0.05)$ so $\mathrm{H}_{0}$ is accepted, indicating that the model is acceptable and the hypothesis test can be measured because there is no significant difference between the model with the observation value.

Table 4. Hosmer and Lemeshow test

\begin{tabular}{lll}
\hline Chi-square & Df & Sig. \\
\hline 11.017 & 8 & 0.201 \\
\hline
\end{tabular}

Table 6. Partial test results of variables

\begin{tabular}{lcccccr}
\hline Variables & B & S.E. & Wald & df & Sig. & Exp(B) \\
\hline Constant & 1.774 & 3.325 & 0.284 & 1 & 0.594 & 5.892 \\
Age & $-0.073 \mathrm{~ns}$ & 0.060 & 1.498 & 1 & 0.221 & 0.929 \\
Education & $1.897 * *$ & 0.730 & 6.761 & 1 & 0.009 & 6.668 \\
Land area & $-0.005 * *$ & 0.002 & 4.544 & 1 & 0.033 & 0.995 \\
Rice seed & $0.185 \mathrm{~ns}$ & 0.125 & 2.199 & 1 & 0.138 & 1.204 \\
Fish seed & $0.143 * *$ & 0.061 & 5.566 & 1 & 0.018 & 1.154 \\
Experience & $0.049 \mathrm{~ns}$ & 0.046 & 1.129 & 1 & 0.288 & 1.051 \\
Interest rate & $-2.559 \mathrm{~ns}$ & 1.603 & 2.547 & 1 & 0.110 & 0.077 \\
Loan procedure & $-3.183 * *$ & 1.614 & 3.888 & 1 & 0.049 & 0.041 \\
Collateral & $-1.281 \mathrm{~ns}$ & 1.421 & 0.812 & 1 & 0.367 & 0.278 \\
\hline
\end{tabular}

Information:

$\begin{array}{ll}* * * & =\text { Significant at confidence level } 99 \% \\ * * & =\text { Significant at confidence level } 95 \% \\ \mathrm{~ns} & =\text { Non-significant }\end{array}$

\subsection{Significant Variables}

The farmer's education level has an effect on the farmer's decision to use the loan at RiceFish farming. Wald's value of 6.761 resulted in pvalue (sig.) of 0.009 which means that farmers with high formal education are more likely to borrow than the low-level farmers. From the table, it can be seen the value of odd ratio (exp (B)) which illustrates the trend of success rate on each independent variable to the dependent
From the Table 5, Chi-square $31.528>$ Chi-square table in df 9 (independent variable 9) which is 16.919 or with significance of 0.000 $(<0.05)$ so that $\mathrm{H}_{0}$ is rejected, indicating that the addition of independent variable can give real influence against the model.

Table 5. Omnibus test of model coefficients

\begin{tabular}{llll}
\hline & Chi-square & df & Sig. \\
\hline Step & 31.528 & 9 & 0.000 \\
Block & 31.528 & 9 & 0.000 \\
Model & 31.528 & 9 & 0.000 \\
\hline
\end{tabular}

Wald Test Statistics is used to partially test the parameters. Seen from the Wald Test, the variables that are affecting farmer's decision use loan are farmer's education level, land area, fish seed, and loan procedure. While the variables that have no significant effect seen from Wald Test are farmer's age, rice seed, experience, interest rate, and collateral. The influence the decision of farmers can be seen in the Table 6 . results of the data to estimate the factors that 
the adoption of agricultural innovation will increase. Education has an effect on one's learning capacity. Farmers who have a high education will try to improve their farming more. Advanced farming can be related to the use of large capital. So that high educated farmers can solve the problem of capital by doing various steps, one of them by using the loan. And from this study, it is known that the level of education has a tendency in making farmer's decisions to use the loan at rich-fish farming in Seyegan District.

The subsequent variables that influence the borrowing decision is the land area with p-value (sig.) of 0.033 and the Wald Test score is 4.544 . Variable land area has odd ratio of 0.995 with negative regression coefficient which means that every farmer who has wide land has opportunity 0.995 times not to make loan than farmer who has narrower land area. Which means that the predicted probability of farmers who has narrower land to borrow money for capital is 0.995. Research conducted by Wati (2015) results that, land area also determines the farmer's opportunities to access loan because it can be regarded as an important asset in farming activities. But, because the regression coefficient result is negative, so in this study it indicates that farmers who have wide land area tend to not to use loan. This is because farmers who have large land have a large income so that the need for capital for their Rice-Fish farming had been fulfilled without having to rely on capital in the form of loans.

The variable of fish seeds used have an effect on the farmer's decision to use the loan with the value of Wald Test of 5.566 and p-value (sig.) of 0.018 . This variable has an odd ratio of 1.154 with a positive regression coefficient indicating that farmers who use the fish seeds more will have a chance of 1.154 to make loan compared to the farmers who use fish seeds less. Which means that the predicted probability of farmers who use the fish seeds more to borrow money for capital is 1.154 . From the results of the research conducted in the field, fish seed variables affect the decision to make loan capital because the Rice-Fish farming in District of Seyegan is relatively new. Farmers initially work on rice farming only before switching to RiceFish farming. Therefore, an increase in the cost of fish seed costs also makes the need for capital increase. One of the things that can be done to cover the cost of fish seeds issued is by using capital loan.
The variable of loan procedure has Wald Test of 3.888 with p-value (sig.) of 0.049 which then affect the farmer's decision to borrow money. Variable loan procedure has odd ratio of 0.041 and negative regression coefficient which means that the perception or big consideration to lending procedure will make farmer decided not to use loan with the predicted probability of 0.041 . The loan procedure is influential in the decision to borrow. This result is similar to the research conducted by Aisyah (2013) which mentioned that the loan procedure has a significant effect on the farmer's interest to borrow. When making the loan, farmers want administrative requirements as easy as possible. Farmers generally do not want to deal with formal loan institutions due to many poorly understood administrative requirements such as completing application forms, opening accounts/savings accounts, approval of husband and wife, letter of collateral, and others. Stringent requirements and administrative procedures are considered complex and take longer. As a result when farmers need immediate funds, the funds are not yet available. Therefore, the procedure affects influences the farmer's decision to use the loan.

\subsection{Non-Significant Variables}

Other variables such as farmer's age, rice seed, experience, interest rate, and collateral do not have statistically significant effect on the loan decision because the p-value (sig.) owned is bigger than 0.05 .

The farmer's age variable is not significant. The average age of farmers in this research location indeed can be said to have a fairly old age of 50 years and above.

The rice seed variable not significant to influence the farmer's decision to use loan. From research conducted in the field, it is known that to fill the needs of rice seeds, farmers usually set aside the harvest to be used as seed in the next planting season. Therefore, rice seed is not quite influential variable in the farmer's decision to use the loan.

The farm experience variable also not significant effect in this research. Experience is an ownership of the knowledge that a person experiences in an unspecified period as a result of his lifelong learning. One's experience can be intertwined in taking interest to borrow. But in this study there is no significant effect between experience and farmer's decision to use the loan. 
The next variable that has no significant effect is the interest rate. This indicates that the farmers of the respondents do not pay much attention to the interest rate in the lending process. This mismatch is caused because the farmers who become respondents in this research assume that the interest rate is a natural thing if the farmers want to do a farming loan. So it does not significantly affect the farmer's decision to borrow money.

The last variable that does not significantly affect the farmer's decision to borrow is collateral. Farmers who become respondents understand the existence of collateral in lending because collateral is the second source of funds to pay off the loan. If the debtor is unable to provide funds to pay interest or repay the loan from the proceeds of the business the creditor may sell the collateral goods into which the loan is approved.

The regression equation can be seen by looking at the constant value which is 1.774 , value of the farmer's age variable is -0.073 , value of the farmer's education level is 1.897 , value of the land area is -0.005 , value of the rice seed is 0.185 , value of the fish seed is 0.143 , value of the experience from being a farmer is 0.049 , value of the interest rate is -2.559 , value of the loan procedure is -3.183 , and value of the collateral is -1.271. From this result obtained model of regression equation:

$$
L_{i}=\operatorname{Ln}\left(\frac{P}{1-P i}\right)=\beta_{0}+\beta_{2} X_{1}+\beta_{2} X_{2}+\ldots+\beta_{n} X_{m}
$$

$\operatorname{Ln}\left(\frac{p}{1-p_{i}^{i}}\right)=1.774-0.073\left(\mathrm{X}_{1}\right)+1.897\left(\mathrm{X}_{2}\right)-$

$0.005\left(\mathrm{X}_{3}\right)+0.185\left(\mathrm{X}_{4}\right)+0.143\left(\mathrm{X}_{5}\right)+0.049$

$\left(\mathrm{X}_{6}\right)-2.559\left(\mathrm{X}_{7}\right)-3.183\left(\mathrm{X}_{8}\right)-1.281\left(\mathrm{X}_{9}\right)$

Where:

$\beta_{0}=$ Constants

$\mathrm{X}_{1}=$ Farmer's age (year)

$\mathrm{X}_{2}=$ Farmer's education level (score)

$\mathrm{X}_{3}=$ Area of land $\left(\mathrm{m}^{2}\right)$

$\mathrm{X}_{4}=$ The use of rice seed $(\mathrm{kg})$

$\mathrm{X}_{5}=$ The use of fish seed $(\mathrm{kg})$

$\mathrm{X}_{6}=$ Farming experience (year)

$\mathrm{X}_{7}=$ Perception about interest rate (score)

$\mathrm{X}_{8}=$ Perception about loan procedure (score)

$\mathrm{X}_{9}=$ Perception about collateral (score)

\section{Conclusion}

Partially, the significant effect on the farmer's decision to use the loan are farmer's education level, land area, the use of fish seed, and the loan procedures. While other variables such as farmer's age, the use of rice seeds, experience, interest rate, and collateral have no significant effect on farmer decision to borrow money.

Knowledge of farmers about loan should be improved by providing regular socialization of the importance of loan for farming development. Farmers who know the loan function for their farm will make farmer's desire to use loan will also be higher.

The need of loan programs from government does not make it difficult for the farmers to access. The loan procedures should be a major concern in improving performance of the loan programs. Therefore, the interest of farmers to use loan from such programs may increase.

In order to increase the interest of farmers in using loan to fill their farming capital requirements, lenders or creditors should pay more attention in terms of procedures in such loan. There is a need for proper formulation in the loan procedures so that the farmers do not find it difficult to access the source of capital that will be helpful in the development of farming, especially Rice-Fish farming.

\section{References}

Aisyah, S. (2013). Analisis Persepsi dan Sikap serta Faktor-faktor yang Mempengaruhi Minat Petani untuk Menggunakan Sumber Pembiayaan Formal Usahatani di Kabupaten Asahan. Universitas Sumatera Utara.

Burhansyah, R. (2014). Faktor-faktor yang Mempengaruhi Adopsi Inovasi Pertanian pada Gapoktan PUAP Dan Non PUAP di Kalimantan Barat. Jurnal Informatika Pertanian, 23(1), 65-74.

Chao, C.-T. (2010). Proportional Sampling. Encyclopedia of Research Design, 1120 1121.

Hendayana, R. (2013). Penerapan Metode Regresi Logistik dalam Menganalisis Adopsi Teknologi Pertanian. Jurnal Informatika Pertanian, 22(1), 1-9.

Hosmer, D. W., \& Lemeshow, S. (2013). Applied Logistic Regression, 3rd Edition.

Lantarsih, R. (2016). Pengembangan "Minapadi Kolam Dalam" di Kabupaten Sleman. AGRARIS: Journal of Agribusiness and Rural Development Research, 2(1), 17-27. 
Lestari, S., \& Bambang, A. N. (2017). Penerapan Minapadi dalam Rangka Mendukung Ketahanan Pangan dan Meningkatkan Kesejahteraan Masyarakat. Proceeding Biology Education Conference, 14(1), 7074.

Perwitasari, H., Suratiyah, K., \& Hardyastuti, S. (2011). Evaluasi Pinjaman Penguatan Modal Bidang Tanaman Pangan dan Hortikultura di Kecamatan Pakem Kabupaten Sleman. Agro Ekonomi, 18(1), 21-32.

Sholihah, H., Hidayat, S. I., \& Yuliati, N. (2014). Persepsi dan Sikap Nasabah dalam Memperoleh Kredit Usaha Agribisnis pada Bank Konvensional dan Bank Syariah. JSEP, 7(1), 24-31.

Susetyo, A. (2011). Analisis Faktor-faktor yang Mempengaruhi Keputusan Pengambilan Kredit di KSP Anugerah Kebumen. Jurnal Fokus Bisnis, 10(2), 1-23.

Wati, D. R. (2015). Akses Kredit Mikro pada Petani Padi Organik di Kabupaten Bogor. Jurnal Agribisnis, 9(2), 97-110. 